\title{
Comparison of the Growth and Mineralization of the Femur, Tibia, and Metatarsus of Broiler Chicks
}

ISSN 1516-635X Jul - Sept 2015 / v.17 / n.3 / 333-340

http://dx.doi.org/10.1590/1516-635x1703333-340

\section{Euthor(s)}

Han JC'

Qu HX

Wang JG',"

Chen $\mathrm{GH}^{\mathrm{I}, \mathrm{ll}}$

Yan $\mathrm{YF}^{\mathrm{I}}$

Zhang J

Hu FM'

You LY'

Cheng $\mathrm{YH}^{\mathrm{II}}$

Department of Animal Science, College of Life Science, Shangqiu Normal University, Shangqiu, China:

" College of Animal Husbandry and Veterinary Science, Henan Agricultural University, Zhengzhou, China;

III Department of Biotechnology and Animal Science, National Ilan University, Taiwan.

\section{Mail Address}

Corresponding author e-mail address Han JC or Yan YF

Department of Animal Science, College of Life Science, Shangqiu Normal University, Shangqiu, 476000, China

E-mail: j.c.han@hotmail.com (or yanyf01@ sina.com)

\section{- Keywords}

Bone, mineralization, calcium, phosphorus, broiler chick.

\section{ABSTRACT}

This study aimed at comparing the growth and mineralization of the femur, tibia, and metatarsus of male and female broiler chicks. On the day of hatch, 100 male and 100 female Ross 308 broiler chicks were transferred stainless cages with 10 birds per cage. On d 7, 14, $21,28,35$, and 42 , five males and five females were sacrificed and their femur, tibia, and metatarsus were collected. Results showed that the tibia was the heaviest and the longest and contained the highest content of ash and calcium ( $\mathrm{Ca}$ ) among the three leg bones. The femur had the greatest diameter. The weight, length, diameter, and ash weight of the femur, tibia, and metatarsus linearly increased with age. The ash, $\mathrm{Ca}$, and phosphorus (P) content in the femur and the tibia quadratically increased with age; by contrast, these parameters in the metatarsus linearly increased with age. The bones grew faster in 1 to $21 \mathrm{~d}$ of age. The weight, diameter, and ash weight of the three bones of males were higher than those of females. The Ca to $P$ ratio of the three bones (femur, tibia, and metatarsus) was approximately 2.0:1. These data indicate that there are differences in bone growth and mineralization among the femur, tibia, and metatarsus of male or female broiler chicks.

\section{INTRODUCTION}

Rapid growth of modern broilers has resulted in skeletal problems, particularly in leg bones, thereby reducing broiler growth performance and increasing mortality. The leg bones of birds include the femur, the tibia, and the metatarsus. Studies have been conducted to determine several characteristics of these leg bones. Skinner \& Waldroup (1995) measured the length, diameter, and ash, calcium (Ca), and phosphorus (P) contents of the tibia of broilers. Barreiro et al. (2011) determined the growth of the femur of broilers. Applegate \& Lilburn (2002) characterized the relationship between growth performance and the development of the tibia and femur in broilers. However, the growth of the metatarsus has not yet been examined. The difference in the growth and mineralization among femur, tibia, and metatarsus remains unknown.

Therefore, this study was conducted to compare the growth and mineralization of the femur, the tibia, and the metatarsus of male and female broilers.

\section{MATERIAL AND METHODS}

All of the procedures used in this study were approved by the Animal Care Committee of Shangqiu Normal University. 


\section{Birds, diets, and management}

On the day of hatch, 100 male and 100 female Ross 308 broiler chicks were housed in stainless-steel cages with 10 birds per cage. Between d 1 and d 14, birds were reared in starter cages $(70 \mathrm{~cm} \times 70 \mathrm{~cm} \times$ $30 \mathrm{~cm}$ ) and on $\mathrm{d} 15$, they were transferred to growerfinisher cages $(190 \mathrm{~cm} \times 50 \mathrm{~cm} \times 35 \mathrm{~cm})$. The birds were supplied with a mash diet (Table 1) and water ad libitum. The lighting program consisted of $24 \mathrm{~h}$ of light from d 0 to d 14, and $20 \mathrm{~h}$ of light from d 15 to $\mathrm{d} 42$. Room temperature was maintained at $33^{\circ} \mathrm{C}$ from $\mathrm{d} 0$ to $\mathrm{d} 3,30^{\circ} \mathrm{C}$ from $\mathrm{d} 4$ to $\mathrm{d} 7,27^{\circ} \mathrm{C}$ from $\mathrm{d} 8$ to $\mathrm{d} 14$, and $20^{\circ} \mathrm{C}$ from d 15 to $\mathrm{d} 42$.

Table 1 - Ingredients and nutrient composition of experimental diets.

\begin{tabular}{lcc}
\hline Ingredients (\%) & 1 to $21 \mathrm{~d}$ & 22 to $42 \mathrm{~d}$ \\
\hline Corn & 56.83 & 61.99 \\
Soybean meal & 32.00 & 28.00 \\
Soybean oil & 1.10 & 2.20 \\
Swine lard & 1.88 & 1.51 \\
Soy protein isolate & 3.98 & 2.74 \\
\hline Limestone & 1.36 & 1.45 \\
\hline Dicalcium phosphate & 1.94 & 1.36 \\
L-Lysine.HCl & 0.14 & 0.14 \\
DL-Methionine & 0.14 & 0.08 \\
\hline Trace mineral premix & 0.10 & 0.10 \\
Vitamin premix & 0.03 & 0.03 \\
Choline chloride & 0.20 & 0.10 \\
\hline Sodium chloride & 0.30 & 0.30 \\
Nutrient composition & & \\
Metabolizable energy (kcal/kg) & 2972 & 3069 \\
\hline Analyzed crude protein (\%) & 21.68 & 19.69 \\
Analyzed calcium (\%) & 0.99 & 0.90 \\
\hline Analyzed total phosphorus (\%) & 0.69 & 0.59 \\
\hline Non-phytate phosphorus (\%) & 0.45 & 0.35 \\
\hline
\end{tabular}

'The trace mineral premix provided the following (per $\mathrm{kg}$ of diet): $100 \mathrm{mg}$ iron; $100 \mathrm{mg}$ zinc; $8 \mathrm{mg}$ copper; $120 \mathrm{mg}$ manganese; $0.7 \mathrm{mg}$ iodine; and $0.3 \mathrm{mg}$ selenium.

${ }^{2}$ The vitamin premix provided the following (per $\mathrm{kg}$ of diet): $8,000 \mathrm{IU}$ vitamin $\mathrm{A} ; 1,000$ IU vitamin $\mathrm{D}_{3} ; 20$ IU vitamin $\mathrm{E} ; 0.5 \mathrm{mg}$ menadione; $2.0 \mathrm{mg}$ thiamine; $8.0 \mathrm{mg}$ riboflavin; $35 \mathrm{mg}$ niacin; $3.5 \mathrm{mg}$ pyridoxine; $0.01 \mathrm{mg}$ vitamin $\mathrm{B}_{12} ; 10.0 \mathrm{mg}$ pantothenic acid; 0.55 $\mathrm{mg}$ folic acid; and $0.18 \mathrm{mg}$ biotin.

\section{Sample collection}

On $\mathrm{d} 7,14,21,28,35$, and 42 , five males and five females were selected and sacrificed. The left femur, tibia, and metatarsus of the birds were excised and frozen at $-20{ }^{\circ} \mathrm{C}$ for subsequent analysis (weight, length, diameter, ash weight, and ash, $\mathrm{Ca}$, and $\mathrm{P}$ contents).

\section{Sample analysis}

Following the method of Hall et al. (2003), the femur, tibia, and metatarsus were boiled for $5 \mathrm{~min}$ to loosen muscle tissues. Muscles, connective tissue, and the fibula bone were completely removed using scissors and forceps. The femur, tibia, and metatarsus were cleaned and then placed in a container with ethanol for $48 \mathrm{~h}$ for the removal of water and polar lipids. Non-polar lipids were extracted by immersing the bones in anhydrous ether for $48 \mathrm{~h}$. Bones were then dried at $105^{\circ} \mathrm{C}$ for $24 \mathrm{~h}$ and weighed. Bone diameter was measured at the medial point. Bones were burnt in a muffle furnace at $600{ }^{\circ} \mathrm{C}$ for $48 \mathrm{~h}$ to determine bone ash weight. Bone ash content is expressed as a percentage of dry bone weight.

Dietary and bone $\mathrm{Ca}$ and $\mathrm{P}$ contents were determined using the ethylene diamine tetraacetic acid (EDTA) titration method and the photometric method after reaction with ammonium molybdate and ammonium metavanadate, respectively. Crude protein $(C P)$ content in the diets was determined by the Kjeldahl method (PN-1430, Barcelona, Spain).

\section{Statistical analysis}

Data were submitted to two-way analysis of variance using SAS software (SAS Institute, 2002). Orthogonal comparisons were performed to determine the linear and quadratic effects of age on bone growth and mineralization. Means were compared by Tukey's test when probability values were significant $(p<0.05)$.

\section{RESULTS AND DISCUSSION}

\section{Bone weight}

The bones weighed from highest to lowest in the following order: tibia $>$ femur $>$ metatarsus (Table 2). Bone weight linearly increased with age. Femur and metatarsus weights were influenced by broiler age and sex $(p<0.05)$. Males presented heavier femur, tibia, and metatarsus than females $(p<0.05)$, particularly in broilers between $\mathrm{d} 28$ and $\mathrm{d} 42$.

Bone weight increase resulted from the increasing feed intake and mineral retention as broilers age; however, dietary $\mathrm{Ca}$ and $\mathrm{P}$ contents decreased from starter to grower-finisher phase. Bones grew faster in the starter phase (1 to $21 \mathrm{~d}$ of age). The bone weight of 14-d-old birds increased by 3.6 times compared with that of 7-d-old birds; by contrast, the weight of 42-d-old broilers only increased by 1.3 times compared with that of 35-d-old broilers.

Male broilers had heavier bone weight than females because males consumed more feed (Skinner \& Waldroup, 1995) and presented greater mineral retention than females. Studies have shown that the weight of the tibia of male chicks is higher than that of females (Bond et al., 1991; Yalcin et al., 2001). 
Table 2 - Comparison of the weight of the femur, tibia, and metatarsus of male and female broilers ${ }^{1}$

\begin{tabular}{|c|c|c|c|c|c|c|c|c|c|}
\hline \multirow{2}{*}{ Age (d) } & \multicolumn{3}{|c|}{ Femur (g) } & \multicolumn{3}{|c|}{ Tibia (g) } & \multicolumn{3}{|c|}{ Metatarsus (g) } \\
\hline & Male & Female & Mean & Male & Female & Mean & Male & Female & Mean \\
\hline 7 & $0.20 \pm 0.01$ & $0.20 \pm 0.01$ & $0.20^{\mathrm{b}}$ & $0.24 \pm 0.01$ & $0.22 \pm 0.03$ & $0.23^{a}$ & $0.16 \pm 0.01$ & $0.16 \pm 0.03$ & $0.16^{c}$ \\
\hline 14 & $0.68 \pm 0.02$ & $0.70 \pm 0.02$ & $0.69^{b}$ & $0.78 \pm 0.07$ & $0.85 \pm 0.06$ & $0.82^{a}$ & $0.48 \pm 0.05$ & $0.52 \pm 0.05$ & $0.50^{c}$ \\
\hline 21 & $1.17 \pm 0.08$ & $1.17 \pm 0.07$ & $1.17^{b}$ & $1.39 \pm 0.13$ & $1.29 \pm 0.08$ & $1.34^{\mathrm{a}}$ & $0.86 \pm 0.12$ & $0.79 \pm 0.04$ & $0.83^{c}$ \\
\hline 28 & $1.76 \pm 0.09$ & $1.72 \pm 0.18$ & $1.74^{\mathrm{b}}$ & $2.18 \pm 0.21$ & $2.12 \pm 0.23$ & $2.15^{a}$ & $1.28 \pm 0.08$ & $1.24 \pm 0.22$ & $1.26^{c}$ \\
\hline 35 & $2.72 \pm 0.19$ & $2.51 \pm 0.22$ & $2.62^{b}$ & $3.47 \pm 0.27$ & $3.10 \pm 0.22$ & $3.28^{a}$ & $2.00 \pm 0.24$ & $1.70 \pm 0.11$ & $1.85^{c}$ \\
\hline 42 & $3.71 \pm 0.23$ & $3.37 \pm 0.17$ & $3.54^{b}$ & $4.69 \pm 0.40$ & $3.97 \pm 0.47$ & $4.33^{\mathrm{a}}$ & $2.54 \pm 0.16$ & $2.22 \pm 0.06$ & $2.38^{c}$ \\
\hline \multicolumn{10}{|c|}{ Source of variation } \\
\hline Age & & $<0.001$ & & & $<0.001$ & & & $<0.001$ & \\
\hline Sex & & 0.005 & & & 0.036 & & & $<0.001$ & \\
\hline Agexsex & & 0.011 & & & 0.152 & & & 0.003 & \\
\hline
\end{tabular}

a-c Means in the same row without common superscript significantly differ $(p<0.05)$

1 Data represent the means of 5 male and 5 female broilers.

Effects of age on bone weight: femur (Linear, $p<0.001$; Quadratic, $p<0.001$ ); tibia (Linear, $p<0.001$; Quadratic, $p<0.001$ ); and metatarsus (Linear, $p<0.001$; Quadratic, $p<$ $0.001)$.

\section{Bone length}

The tibia was the longest leg bone (Table 3). The femur was longer than the metatarsus from 7 to 28 $d$ of age $(p<0.05)$. However, no differences in length were observed between the femur and the metatarsus from 35 to $42 \mathrm{~d}$ of age ( $p>0.05$ ). Bone length linearly increased with age. Age and sex affected the length of the tibia and the metatarsus $(p<0.01)$.

The tibia was longer than the femur and the metatarsus in broilers. Goetting-Fuchs et al. (2012) observed similar results in turkeys; in particular, the tibia is the longest bone, followed by the metatarsus and the femur in 2- to 22-wk-old turkeys. In the present study, no differences in the bone length were observed between male and female broilers. However, Bond et al. (1991) found that males had longer tibia than females.

\section{Bone diameter}

Femur had the greatest diameter (Table 4). No differences $(p>0.05)$ in the diameter of the tibia and the metatarsus were observed (except at $7 \mathrm{~d}$ of age). Bone diameter linearly increased with age. Age and sex influenced the diameter of the femur and the metatarsus $(p<0.05)$. The bone diameter of males was greater than that of females $(p<0.05)$, particularly from 35 to $42 \mathrm{~d}$ of age.

The bone diameter of 12 - to 20-wk-old turkeys varied in the following order: tibia $>$ femur $>$ metatarsus (Goetting-Fuchs et al., 2012). In the present study, the bone diameter of the males was greater than that of the females. Applegate \& Lilburn (2002) reported that 28- to 43-d-old male broilers had greater tibia diameter than females of the same age; however, no differences

Table 3 - Comparison of the length of the femur, tibia, and metatarsus of male and female broilers ${ }^{1}$.

\begin{tabular}{|c|c|c|c|c|c|c|c|c|c|}
\hline \multirow{2}{*}{ Age(d) } & \multicolumn{3}{|c|}{ Femur $(\mathrm{cm})$} & \multicolumn{3}{|c|}{ Tibia $(\mathrm{cm})$} & \multicolumn{3}{|c|}{ Metatarsus (cm) } \\
\hline & Male & Female & Mean & Male & Female & Mean & Male & Female & Mean \\
\hline 7 & $2.83 \pm 0.06$ & $2.82 \pm 0.14$ & $2.83^{b}$ & $3.59 \pm 0.15$ & $3.76 \pm 0.09$ & $3.67^{\mathrm{a}}$ & $2.60 \pm 0.19$ & $2.70 \pm 0.05$ & $2.65^{c}$ \\
\hline 14 & $3.84 \pm 0.16$ & $3.89 \pm 0.11$ & $3.86^{\mathrm{b}}$ & $4.93 \pm 0.34$ & $5.09 \pm 0.15$ & $5.01^{\mathrm{a}}$ & $3.47 \pm 0.15$ & $3.63 \pm 0.08$ & $3.55^{c}$ \\
\hline 21 & $4.57 \pm 0.11$ & $4.61 \pm 0.04$ & $4.59^{b}$ & $6.04 \pm 0.21$ & $6.00 \pm 0.11$ & $6.02^{\mathrm{a}}$ & $4.25 \pm 0.20$ & $4.15 \pm 0.08$ & $4.20^{c}$ \\
\hline 28 & $5.09 \pm 0.08$ & $5.40 \pm 0.09$ & $5.25^{b}$ & $6.97 \pm 0.17$ & $7.16 \pm 0.07$ & $7.06^{\mathrm{a}}$ & $4.82 \pm 0.13$ & $4.95 \pm 0.15$ & $4.89^{c}$ \\
\hline 35 & $5.74 \pm 0.29$ & $6.05 \pm 0.23$ & $5.90^{\mathrm{b}}$ & $8.34 \pm 0.41$ & $8.22 \pm 0.25$ & $8.28^{a}$ & $5.83 \pm 0.26$ & $5.77 \pm 0.16$ & $5.80^{b}$ \\
\hline 42 & $6.38 \pm 0.72$ & $6.20 \pm 0.60$ & $6.29^{b}$ & $9.46 \pm 0.20$ & $8.98 \pm 0.10$ & $9.22^{\mathrm{a}}$ & $6.68 \pm 0.26$ & $6.30 \pm 0.18$ & $6.49^{b}$ \\
\hline \multicolumn{10}{|c|}{ Source of variation } \\
\hline Age & & $<0.001$ & & & $<0.001$ & & & $<0.001$ & \\
\hline Sex & & 0.296 & & & 0.713 & & & 0.577 & \\
\hline Agexsex & & 0.429 & & & 0.007 & & & 0.008 & \\
\hline
\end{tabular}

a-c Means in the same row without common superscript significantly differ $(p<0.05)$.

${ }^{1}$ Data represent the means of 5 male and 5 female broilers.

Effects of age on bone length: femur (Linear, $p<0.001$; Quadratic, $p<0.001$ ); tibia (Linear, $p<0.001$; Quadratic, $p=0.089$ ); and metatarsus (Linear, $p<0.001$; Quadratic, $p=$ $0.987)$. 
Table 4 - Comparison of the diameter of the femur, tibia, and metatarsus of male and female broilers ${ }^{1}$

\begin{tabular}{|c|c|c|c|c|c|c|c|c|c|}
\hline \multirow{2}{*}{ Age (d) } & \multicolumn{3}{|c|}{ Femur $(\mathrm{cm})$} & \multicolumn{3}{|c|}{ Tibia $(\mathrm{cm})$} & \multicolumn{3}{|c|}{ Metatarsus (cm) } \\
\hline & Male & Female & Mean & Male & Female & Mean & Male & Female & Mean \\
\hline 7 & $0.33 \pm 0.01$ & $0.32 \pm 0.01$ & $0.32^{\mathrm{a}}$ & $0.29 \pm 0.01$ & $0.27 \pm 0.01$ & $0.28^{b}$ & $0.25 \pm 0.02$ & $0.24 \pm 0.01$ & $0.25^{c}$ \\
\hline 14 & $0.50 \pm 0.03$ & $0.52 \pm 0.02$ & $0.51^{\mathrm{a}}$ & $0.40 \pm 0.03$ & $0.43 \pm 0.01$ & $0.41^{\mathrm{b}}$ & $0.41 \pm 0.03$ & $0.42 \pm 0.02$ & $0.41^{b}$ \\
\hline 21 & $0.65 \pm 0.03$ & $0.64 \pm 0.04$ & $0.65^{a}$ & $0.50 \pm 0.04$ & $0.48 \pm 0.01$ & $0.49^{b}$ & $0.51 \pm 0.02$ & $0.51 \pm 0.04$ & $0.51^{b}$ \\
\hline 28 & $0.82 \pm 0.04$ & $0.75 \pm 0.04$ & $0.79^{a}$ & $0.58 \pm 0.03$ & $0.57 \pm 0.04$ & $0.58^{b}$ & $0.53 \pm 0.01$ & $0.55 \pm 0.06$ & $0.54^{b}$ \\
\hline 35 & $1.01 \pm 0.04$ & $0.89 \pm 0.06$ & $0.95^{\mathrm{a}}$ & $0.71 \pm 0.07$ & $0.66 \pm 0.02$ & $0.69^{b}$ & $0.69 \pm 0.02$ & $0.59 \pm 0.01$ & $0.64^{b}$ \\
\hline 42 & $1.04 \pm 0.11$ & $0.97 \pm 0.07$ & $1.01^{\mathrm{a}}$ & $0.75 \pm 0.08$ & $0.68 \pm 0.03$ & $0.71^{\mathrm{b}}$ & $0.70 \pm 0.05$ & $0.64 \pm 0.04$ & $0.67^{b}$ \\
\hline \multicolumn{10}{|c|}{ Source of variation } \\
\hline Age & & $<0.001$ & & & $<0.001$ & & & $<0.001$ & \\
\hline Sex & & 0.002 & & & 0.017 & & & 0.003 & \\
\hline Agexsex & & 0.035 & & & 0.115 & & & $<0.001$ & \\
\hline
\end{tabular}

a-c Means in the same row without common superscript significantly differ $(p<0.05)$

1 Data represent the means of 5 male and 5 female broilers.

Effects of the age on bone diameter: femur (Linear, $p<0.001$; Quadratic, $p=0.002$ ); tibia (Linear, $p<0.001$; Quadratic, $p=0.002$ ); and metatarsus (Linear, $p<0.001$; Quadratic, $p<0.001)$.

were observed in tibia diameter between males and females from 8 to $21 \mathrm{~d}$ of age.

\section{Bone ash weight}

Among the three bones, tibia had the heaviest ash weight (Table 5). Bone ash weight linearly increased with age. Age and sex influenced the ash weight of the femur and the metatarsus $(p<0.05)$; in particular, the ash weight of males was higher than that of females.

Minerals are retained faster in the bones during the starter phase. Ash weight at $14 \mathrm{~d}$ of age was 3.9 times higher compared with that obtained at $7 \mathrm{~d}$ of age. By contrast, ash weight at $42 \mathrm{~d}$ of age was 1.3 times higher compared with that of $35 \mathrm{~d}$ of age. The ash weight of the femur and metatarsus of males was higher than that of females in the present study. Bond et al. (1991) found that the tibia ash weight of male broilers was higher than that of females.

\section{Bone ash content}

Tibia presented the highest ash content (Table 6). No differences were observed in the ash content of the femur and the metatarsus from 7 to $21 \mathrm{~d}$ of age $(p>0.05)$. The ash content of the femur was higher than that of the metatarsus at $28 d$ of age $(p<0.05)$. However, the ash content of the femur was lower than that of the metatarsus from 35 to $42 \mathrm{~d}$ of age ( $p<$ 0.05). The bone ash content of the femur and the tibia quadratically increased with age. The highest ash content was observed at $28 \mathrm{~d}$ of age. By contrast, the ash content of the metatarsus linearly increased with age. Age and sex influenced the ash content of the metatarsus $(p=0.01)$.

Yair et al. (2012) observed different ash content among leg bones; in particular, the ash content of the tibia was lower than that of the femur in embryos between $14 \mathrm{~d}$ and $19 \mathrm{~d}$ of incubation, whereas the

Table 5 - Comparison of the ash weight of the femur, tibia, and metatarsus of male and female broilers ${ }^{1}$.

\begin{tabular}{|c|c|c|c|c|c|c|c|c|c|}
\hline \multirow{2}{*}{ Age (d) } & \multicolumn{3}{|c|}{ Femur (g) } & \multicolumn{3}{|c|}{ Tibia (g) } & \multicolumn{3}{|c|}{ Metatarsus (g) } \\
\hline & Male & Female & Mean & Male & Female & Mean & Male & Female & Mean \\
\hline 7 & $0.09 \pm 0.00$ & $0.08 \pm 0.00$ & $0.09^{b}$ & $0.12 \pm 0.00$ & $0.11 \pm 0.01$ & $0.11^{\mathrm{a}}$ & $0.07 \pm 0.00$ & $0.07 \pm 0.00$ & $0.07 c$ \\
\hline 14 & $0.32 \pm 0.01$ & $0.33 \pm 0.01$ & $0.33^{b}$ & $0.41 \pm 0.03$ & $0.45 \pm 0.03$ & $0.43^{\mathrm{a}}$ & $0.23 \pm 0.02$ & $0.25 \pm 0.02$ & $0.24^{c}$ \\
\hline 21 & $0.55 \pm 0.03$ & $0.56 \pm 0.03$ & $0.56^{b}$ & $0.74 \pm 0.07$ & $0.69 \pm 0.04$ & $0.72^{\mathrm{a}}$ & $0.41 \pm 0.06$ & $0.38 \pm 0.02$ & $0.40^{c}$ \\
\hline 28 & $0.86 \pm 0.05$ & $0.84 \pm 0.09$ & $0.85^{b}$ & $1.17 \pm 0.13$ & $1.14 \pm 0.10$ & $1.16^{\mathrm{a}}$ & $0.60 \pm 0.05$ & $0.61 \pm 0.12$ & $0.60^{c}$ \\
\hline 35 & $1.29 \pm 0.05$ & $1.18 \pm 0.12$ & $1.24^{b}$ & $1.79 \pm 0.33$ & $1.66 \pm 0.11$ & $1.73^{\mathrm{a}}$ & $0.98 \pm 0.13$ & $0.85 \pm 0.05$ & $0.91^{c}$ \\
\hline 42 & $1.71 \pm 0.16$ & $1.55 \pm 0.10$ & $1.63^{b}$ & $2.44 \pm 0.55$ & $2.08 \pm 0.24$ & $2.26^{a}$ & $1.28 \pm 0.10$ & $1.12 \pm 0.03$ & $1.20^{c}$ \\
\hline \multicolumn{10}{|c|}{ Source of variation } \\
\hline Age & \multicolumn{3}{|c|}{$<0.001$} & \multicolumn{3}{|c|}{$<0.001$} & \multicolumn{3}{|c|}{$<0.001$} \\
\hline Sex & \multicolumn{3}{|c|}{0.019} & \multicolumn{3}{|c|}{0.103} & \multicolumn{3}{|c|}{0.009} \\
\hline Agexsex & \multicolumn{3}{|c|}{0.043} & \multicolumn{3}{|c|}{0.331} & \multicolumn{3}{|c|}{0.013} \\
\hline
\end{tabular}

a-c Means in the same row without common superscript significantly differ $(p<0.05)$.

Data represent the means of 5 male and 5 female broilers.

Effects of age on bone ash weight: femur (Linear, $p<0.001$; Quadratic, $p<0.001$ ); tibia (Linear, $p<0.001$; Quadratic, $p<0.001$ ); and metatarsus (Linear, $p<0.001 ;$ Quadratic, $p$ $<0.001)$. 
Table 6 - Comparison of the ash content of the femur, tibia, and metatarsus of male and female broilers1.

\begin{tabular}{|c|c|c|c|c|c|c|c|c|c|}
\hline \multirow{2}{*}{ Age (d) } & \multicolumn{3}{|c|}{ Femur (\%) } & \multicolumn{3}{|c|}{ Tibia (\%) } & \multicolumn{3}{|c|}{ Metatarsus (\%) } \\
\hline & Male & Female & Mean & Male & Female & Mean & Male & Female & Mean \\
\hline 7 & $43.9 \pm 0.2$ & $43.4 \pm 0.8$ & $43.7^{b}$ & $49.4 \pm 1.0$ & $49.3 \pm 0.7$ & $49.4^{a}$ & $43.7 \pm 0.5$ & $42.6 \pm 1.4$ & $43.1^{b}$ \\
\hline 14 & $47.5 \pm 0.8$ & $48.0 \pm 0.6$ & $47.8^{b}$ & $53.1 \pm 0.7$ & $53.3 \pm 0.6$ & $53.2^{\mathrm{a}}$ & $48.2 \pm 0.7$ & $47.6 \pm 1.0$ & $47.9^{b}$ \\
\hline 21 & $47.4 \pm 1.5$ & $47.9 \pm 1.2$ & $47.6^{\mathrm{b}}$ & $53.3 \pm 0.9$ & $53.6 \pm 0.4$ & $53.5^{a}$ & $47.5 \pm 1.0$ & $48.4 \pm 0.5$ & $48.0^{\mathrm{b}}$ \\
\hline 28 & $48.9 \pm 0.6$ & $49.0 \pm 0.6$ & $49.0^{b}$ & $53.7 \pm 1.4$ & $53.9 \pm 1.4$ & $53.8^{\mathrm{a}}$ & $47.3 \pm 0.9$ & $48.2 \pm 0.1$ & $47.8^{c}$ \\
\hline 35 & $47.5 \pm 1.7$ & $47.1 \pm 1.2$ & $47.3^{c}$ & $51.6 \pm 1.7$ & $53.7 \pm 0.8$ & $52.6^{\mathrm{a}}$ & $49.1 \pm 0.8$ & $50.1 \pm 0.8$ & $49.6^{b}$ \\
\hline 42 & $46.0 \pm 1.7$ & $45.8 \pm 1.5$ & $45.9^{c}$ & $51.8 \pm 1.8$ & $52.5 \pm 0.9$ & $52.1^{\mathrm{a}}$ & $50.1 \pm 0.8$ & $50.6 \pm 0.2$ & $50.4^{b}$ \\
\hline \multicolumn{10}{|c|}{ Source of variation } \\
\hline Age & & $<0.001$ & & & $<0.001$ & & & $<0.001$ & \\
\hline Sex & & 0.968 & & & 0.051 & & & 0.237 & \\
\hline Agexsex & & 0.871 & & & 0.345 & & & 0.010 & \\
\hline
\end{tabular}

acc Means in the same row without common superscript significantly differ $(p<0.05)$.

${ }^{1}$ Data represent the means of 5 male and 5 female broilers.

Effects of age on bone ash content: femur (Linear, $p<0.001$; Quadratic, $p<0.001$ ); tibia (Linear, $p<0.001$; Quadratic, $p<0.001$ ); and metatarsus (Linear, $p<0.001$; Quadratic, $p<0.001)$.

tibia presented higher ash content than the femur in broilers post-hatch, between 3 and $7 \mathrm{~d}$ of age.

The rapid formation and mineralization of the tibia of broiler chicks occur from d 4 to $\mathrm{d} 18$ and from $\mathrm{d} 4$ to $d 11$, respectively (Williams et al., 2000). The ash content of the tibia increases from 8 to $22 \mathrm{~d}$ of age; however, this value decreased at $42 \mathrm{~d}$ of age (Barreiro et al., 2011), indicated that bones grow faster during the starter phase compared with the finisher phase. In the present study, the ash content of the femur and tibia quadratically increased with age; by contrast, the ash content of the metatarsus linearly increased with age. The metatarsus exhibited the lowest breaking-strength among leg bones (femur, tibia, and metatarsus); however, the highest body weight (g) endured by per breaking-strength $(\mathrm{N})$ was observed in the metatarsus (g/N) (Gu et al., 2010). Therefore, the metatarsus should constantly retain minerals to sustain the body weight of broiler chicks.

Sex did not affect the ash content of leg bones in the present study and no differences were observed in the ash content of the tibia of male and female broilers in previous studies (Bond et al., 1991; Yalcin et al., 2001).

\section{Bone Ca content}

The highest Ca content was observed in the tibia (Table 7). No differences in Ca content were observed between the femur and the metatarsus from 7 to 28 $d$ of age $(p>0.05)$. However, the femur exhibited a lower Ca content than the metatarsus from 35 to 42 $d$ of age $(p<0.05)$. The Ca content of the femur and the tibia quadratically increased with age. The highest Ca content was observed on 28 and $21 \mathrm{~d}$ of age in the femur and the tibia, respectively. By contrast, the $\mathrm{Ca}$

Table 7 - Comparison of the calcium (Ca) content of the femur, tibia, and metatarsus of male and female broilers'.

\begin{tabular}{|c|c|c|c|c|c|c|c|c|c|}
\hline \multirow{2}{*}{ Age (d) } & \multicolumn{3}{|c|}{ Femur (\%) } & \multicolumn{3}{|c|}{ Tibia (\%) } & \multicolumn{3}{|c|}{ Metatarsus (\%) } \\
\hline & Male & Female & Mean & Male & Female & Mean & Male & Female & Mean \\
\hline 7 & $15.6 \pm 0.8$ & $15.6 \pm 0.6$ & $15.6^{b}$ & $17.5 \pm 0.6$ & $17.8 \pm 0.5$ & $17.6^{a}$ & $15.4 \pm 0.4$ & $15.3 \pm 0.6$ & $15.3^{b}$ \\
\hline 14 & $17.0 \pm 0.3$ & $17.4 \pm 0.2$ & $17.2^{\mathrm{b}}$ & $19.1 \pm 0.3$ & $19.0 \pm 0.3$ & $19.1^{\mathrm{a}}$ & $17.5 \pm 0.4$ & $17.2 \pm 0.5$ & $17.3^{b}$ \\
\hline 21 & $17.5 \pm 0.6$ & $17.5 \pm 0.5$ & $17.5^{b}$ & $19.3 \pm 0.6$ & $19.9 \pm 0.1$ & $19.6^{a}$ & $18.0 \pm 0.8$ & $18.2 \pm 0.7$ & $18.1^{\mathrm{b}}$ \\
\hline 28 & $17.4 \pm 0.5$ & $17.8 \pm 0.3$ & $17.6^{\mathrm{b}}$ & $18.8 \pm 0.5$ & $19.0 \pm 0.5$ & $18.9^{\mathrm{a}}$ & $17.7 \pm 0.4$ & $18.1 \pm 0.5$ & $17.9^{b}$ \\
\hline 35 & $17.3 \pm 0.7$ & $17.7 \pm 0.6$ & $17.5^{\mathrm{b}}$ & $18.5 \pm 0.7$ & $19.0 \pm 0.3$ & $18.7^{\mathrm{a}}$ & $18.3 \pm 0.2$ & $18.1 \pm 0.9$ & $18.2^{\mathrm{a}}$ \\
\hline 42 & $17.4 \pm 0.7$ & $17.5 \pm 0.5$ & $17.4^{\mathrm{b}}$ & $18.6 \pm 0.7$ & $18.7 \pm 0.7$ & $18.6^{\mathrm{a}}$ & $18.7 \pm 0.3$ & $18.8 \pm 0.1$ & $18.7^{\mathrm{a}}$ \\
\hline \multicolumn{10}{|c|}{ Source of variation } \\
\hline Age & & $<0.001$ & & & $<0.001$ & & & $<0.001$ & \\
\hline Sex & & 0.105 & & & 0.067 & & & 0.961 & \\
\hline Agexsex & & 0.888 & & & 0.677 & & & 0.812 & \\
\hline
\end{tabular}

$a, b$ Means in the same row without common superscript significantly differ $(p<0.05)$.

${ }^{1}$ Data represent the means of 5 male and 5 female broilers.

Effects of the age on bone Ca content: femur (Linear, $p<0.001$; Quadratic, $p<0.001$ ); tibia (Linear, $p=0.025$; Quadratic, $p<0.001$ ); and metatarsus (Linear, $p<0.001$; Quadratic, $p<0.001)$. 
Table 8 - Comparison of the phosphorus (P) content of the femur, tibia, and metatarsus of male and female broilers ${ }^{1}$.

\begin{tabular}{|c|c|c|c|c|c|c|c|c|c|}
\hline \multirow{2}{*}{ Age (d) } & \multicolumn{3}{|c|}{ Femur (\%) } & \multicolumn{3}{|c|}{ Tibia (\%) } & \multicolumn{3}{|c|}{ Metatarsus (\%) } \\
\hline & Male & Female & Mean & Male & Female & Mean & Male & Female & Mean \\
\hline 7 & $8.39 \pm 0.10$ & $7.86 \pm 0.19$ & $8.12^{b}$ & $8.65 \pm 0.31$ & $8.75 \pm 0.24$ & $8.70^{a}$ & $7.45 \pm 0.43$ & $7.27 \pm 0.31$ & $7.36^{c}$ \\
\hline 14 & $8.53 \pm 0.14$ & $8.72 \pm 0.18$ & $8.62^{b}$ & $9.45 \pm 0.25$ & $9.30 \pm 0.16$ & $9.38^{a}$ & $8.47 \pm 0.11$ & $8.39 \pm 0.51$ & $8.43^{b}$ \\
\hline 21 & $8.58 \pm 0.32$ & $8.76 \pm 0.30$ & $8.67^{b}$ & $9.18 \pm 0.38$ & $9.17 \pm 0.42$ & $9.17^{a}$ & $8.45 \pm 0.28$ & $8.64 \pm 0.10$ & $8.55^{b}$ \\
\hline 28 & $8.82 \pm 0.47$ & $8.88 \pm 0.16$ & $8.85^{\mathrm{ab}}$ & $9.09 \pm 0.27$ & $9.03 \pm 0.36$ & $9.06^{a}$ & $8.43 \pm 0.23$ & $8.60 \pm 0.42$ & $8.51^{b}$ \\
\hline 35 & $8.56 \pm 0.31$ & $8.61 \pm 0.24$ & $8.58^{\mathrm{b}}$ & $8.97 \pm 0.25$ & $9.04 \pm 0.46$ & $9.01^{a}$ & $8.88 \pm 0.29$ & $8.97 \pm 0.44$ & $8.92^{\mathrm{ab}}$ \\
\hline 42 & $8.46 \pm 0.34$ & $8.38 \pm 0.23$ & $8.42^{c}$ & $8.66 \pm 0.26$ & $8.70 \pm 0.18$ & $8.68^{b}$ & $9.14 \pm 0.18$ & $9.30 \pm 0.18$ & $9.22^{\mathrm{a}}$ \\
\hline \multicolumn{10}{|c|}{ Source of variation } \\
\hline Age & & $<0.001$ & & & $<0.001$ & & & $<0.001$ & \\
\hline Sex & & 0.756 & & & 0.998 & & & 0.482 & \\
\hline Agexsex & & 0.042 & & & 0.952 & & & 0.718 & \\
\hline
\end{tabular}

a-c Means in the same row without common superscript significantly differ $(p<0.05)$

${ }^{1}$ Data represent the means of 5 male and 5 female broilers.

Effects of age on bone P content: femur (Linear, $p=0.043$; Quadratic, $p<0.001$ ); tibia (Linear, $p=0.097$; Quadratic, $p<0.001$ ); and metatarsus (Linear, $p<0.001$; Quadratic, $p$ $=0.004$ ).

content of the metatarsus linearly increased with age. No differences in Ca content were observed between male and female broilers ( $p>0.05$ ).

Differences in the Ca content of leg bones were observed in turkeys. The femur contained higher $\mathrm{Ca}$ than the tibia in 2- to 22-wk-old turkeys (GoettingFuchs et al., 2012). These data showed the different ability of leg bones to retain minerals.

In our study, the Ca content of the tibia and femur quadratically increased with age. This result is consistent with that reported by Barreiro et al. (2009). Talaty et al. (2009) also found that chicks exhibited the greatest tibia mineral density at $28 \mathrm{~d}$ of age. Similarly to ash content, metatarsus Ca content linearly increased with age.

No differences in bone $\mathrm{Ca}$ content were observed between males and females in the present study. A previous research showed that male broilers present lower tibia $\mathrm{Ca}$ than females from 42 to $56 \mathrm{~d}$ of age (Skinner \& Waldroup, 1995).

\section{Bone P content}

Tibia had the highest $P$ content from 7 to $35 \mathrm{~d}$ of age. No differences were observed in the $P$ content of the femur and the metatarsus from 14 to $35 \mathrm{~d}$ of age $(p>0.05)$. The metatarsus had the largest $P$ content, followed by tibia and femur at $42 \mathrm{~d}$ of age $(p<0.05)$. The $P$ content of the femur and the tibia quadratically increased with age and reached the highest value at 28 and $14 \mathrm{~d}$ of age, respectively. By contrast, the $\mathrm{P}$ content of the metatarsus linearly increased with age. No differences in bone $P$ content were observed between males and females ( $p>0.05)$.

Goetting-Fuchs et al. (2012) reported that femur $\mathrm{P}$ content was higher than that of the tibia in 2- to 22-wk-old turkeys.
The lowest $P$ content of the tibia was observed at 8 $\mathrm{d}$ of age and then increased at $22 \mathrm{~d}$ of age; however, $\mathrm{P}$ content did not increase at $42 \mathrm{~d}$ of age (Barreiro et al., 2009). The percentage of $C a$ and $P$ of the whole body decreased in broilers from 3 to 6 wk of age (Nieß et al., 2005). These data suggested that the $P$ is retained faster in the tibia and the whole body during starter phase.

Skinner \& Waldroup (1995) and Barreiro et al. (2009) found that the $\mathrm{Ca}$ to $\mathrm{P}$ ratio in the tibia of broilers was 2.0:1. Similar results were observed in the present study; in particular, the Ca to P ratio in the femur, tibia, and metatarsus was also approximately 2.0:1.

In conclusion, the leg bones of broiler chicks grew faster at 1 to $21 \mathrm{~d}$ of age compared with 22 to $42 \mathrm{~d}$ of age. The retention of $\mathrm{Ca}$ and $\mathrm{P}$ was related with the ash content in the three leg bones. These data indicate that there are differences in femur, tibia, and metatarsus growth and mineralization of male and female broilers.

\section{ACKNOWLEDGMENTS}

This study was supported by the National Natural Science Foundation of China (31101732), Innovation Scientists and Technicians Troop Construction Projects of Henan Province, and Shangqiu Normal University Foundation (2013GGJS10).

\section{REFERENCES}

Applegate TJ, Lilburn MS. Growth of the femur and tibia of a commercial broiler line. Poultry Science 2002;81:1289-1294.

Barreiro FR, Baraldi-Artoni SM, Amaral LA, Barbosa JC, Girardi AM, Pacheco MR, Amoroso L. Determination of broiler femur parameters at different growth phases. International Journal of Poultry Science 2011;10:849853. 
Barreiro FR, Sagula AL, Junqueira OM, Pereira GT, Baraldi-Artoni, SM. Densitometric and biochemical values of broiler tibias at different ages. Poultry Science 2009;88:2644-2648.

Bond PL, Sullivan TW, Douglas JH, Robeson LG. Influence of age, sex, and method of rearing on tibia length and mineral deposition in broilers. Poultry Science 1991;70:1936-1942.

Goetting-Fuchs C, Günther R, Liesner VG, Liesner BG, Beyerbach $\mathrm{M}$, Kamphues J. Investigations on skeletal development, bone mineralisation as well as calcium and phosphorus levels in blood of male fattening turkeys. European Poultry Science 2012;76:121-130.

Gu R, Tang XJ, Lu JX, Ge QL, Gao YS. Comparison on bone strength of four breeds of commercial generation broilers. China Poultry 2010;32:2830.

Hall LE, Shirley RB, Bakalli RI, Aggrey SE, Pesti GM, Edwards HM Jr. Power of two methods for the estimation of bone ash of broilers. Poultry Science 2003:82:414-418

Nieß $E$, Hovenjürgen $M$, Pfeffer $E$. Whole body concentrations of major minerals and of some trace elements in 3,5 and 6 weeks old broiler chicks. European Poultry Science 2005;69:16-22.
SAS Institute. SAS user's guide. Version 9 ed. Cary; 2002.

Skinner JT, Waldroup PW. Allometric bone development in floor-reared broilers. Journal of Applied Poultry Research 1995;4:265-270.

Talaty PN, Katanbaf MN, Hester PY. Life cycle changes in bone mineralization and bone size traits of commercial broilers. Poultry Science 2009;88:1070-1077.

Williams B, Solomon S, Waddington D, Thorp B, Farquharson C. Skeletal development in the meat-type chicken. British Poultry Science 2000;41:141-149

Yair R, Uni Z, Shahar R. Bone characteristics of late-term embryonic and hatchling broilers: Bone development under extreme growth rate. Poultry Science 2012;91:2614-2620.

Yalcin S, Ozkan S, Coskuner E, Bilgen G, Delen Y, Kurtulmus Y, Tanyalcin T. Effects of strain, maternal age and sex on morphological characteristics and composition of tibial bone in broilers. British Poultry Science 2001;42:184-190 
